\title{
Exposure of US youth to cigarette television advertising in the 1960s
}

\author{
Richard W Pollay
}

\begin{abstract}
Objective - To assess the efficacy of the US cigarette industry's self-regulation of 1963 broadcast advertising, following Tobacco Institute guidelines to avoid youthful audiences.
\end{abstract}

Data source-Federal Trade Commission (FTC) Report (1964) on Cigarette Advertising and Output (Appendix B Audience Composition of Television Programs Sponsored by Cigarette Manufacturers, autumn 1963). Supplemented by 1963 census information and trade data on spot television buying.

Methods - FTC data recast by firm and by time of day. Statistical analysis to identify firms deviating from the industry norms for realised audiences, and the apparent target audience for the pattern of time slots sponsored. Total television cigarette ad exposures estimated for children, teenagers, and adults.

Results-Cigarette firms sponsored 55 network television shows in 125 half-hour time slots in 1963, with all firms participating. Children and teens constituted from $24 \%$ to $30 \%$ of the bought network television audiences for all firms except Brown \& Williamson. The average teenager saw an estimated 26 cigarette television ads a week, or over 100 per month. The amount of cigarette sponsorship in prime-time slots was significantly correlated with the delivered proportions of teenagers, not adults.

Conclusions - Observed patterns of television sponsorship by US firms in 1963 were consistent with the cigarette industry's strategic interest in reaching the young. The Tobacco Institute's 1963 efforts at self-regulation were inadequate to protect youth in the US from the inducements of cigarette advertising on television.

(Tobacco Control 1994; 3 : 130-133)

\section{Introduction}

History of Advertising Archives,

Faculty of Commerce, University of British Columbia,

Vancouver, Canada

V6T 1Z2

$\mathrm{R}$ W Pollay vision set as the "greatest cigarette machine ever devised." Judging by the hear spending on television in the 1960 s by all six firms in the US cigarette oligopoly, they agreed. The intensive advertising efforts placing heavy reliance on television were detailed in the tobacco trade press for many of the firms: RJ Reynolds, ${ }^{2}$ Philip Morris, ${ }^{3}$ Liggett \& Myers, ${ }^{4}$ and Brown \& Williamson. ${ }^{5}$

The cigarette industry provided more than $10 \%$ of the television networks' advertising revenue in 1963. There were several time slots when tobacco companies simultaneously sponsored programmes on all three networks, creating what is known as a "roadblock", with cigarette ad exposure inevitable no matter which network or programme was watched. Each network also had at least three nights of the week with cigarette sponsors in virtually every evening prime-time slot. Advertising Age noted the heavy reliance on television and the ever-increasing trends in ad spending, cigarette sales, and corporate profits. Cigarette advertising spending rose an impressive $179 \%$ between 1950 and 1960, the decade of the first "health scare". Per capita consumption over this decade increased by $17 \%$, in apparent response to these persistent inducements. ${ }^{6}$

US cigarette advertising in 1963 faced mounting criticism, however, from the advertising trade as elsewhere, and the first US Surgeon General's report on smoking and health was in its final stage of preparation. The cigarette industry convened as the Tobacco Institute to discuss how to manage its television advertising in response to the growing concerns. ${ }^{7}$ The resulting self-regulatory principles included one that programmes "whose content is directed particularly at youthful audiences should not be sponsored or used". The chief executive officers of all the major US cigarette firms, save for Brown \& Williamson, instantly endorsed the Tobacco Institute suggestions, indicating that they would display the necessary judgement and self-regulatory restraint, with several claiming that their policies already conformed to these principles. ${ }^{8}$

The purpose of this analysis is to examine the efficacy of this apparent self-regulation. Television is an apt focus of study not only because it was the focus of criticism and Tobacco Institute suggestions, but also because of available reliable and exhaustive data, and because television commanded the lion's share $(62 \%)$ of cigarette advertising on measured media in 1963. Total cigarette promotional spending for 1963 was reported to be just over 250 million dollars, about one twelfth of the total being spent by the entire top 100 national advertisers. ${ }^{9}$ 


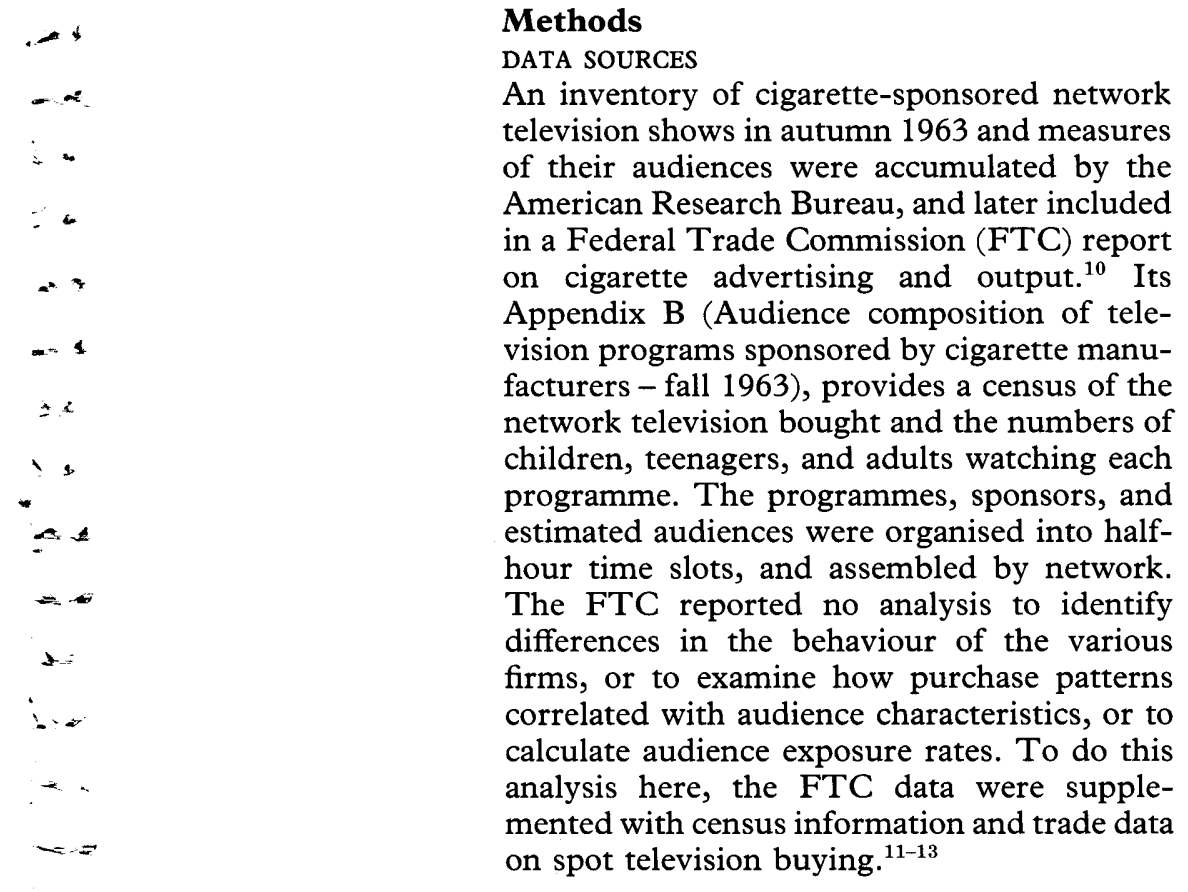

$\cdots$

i.

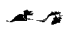

2

$=$

-

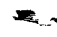

2

$-\infty$

$\therefore$

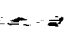

$-$

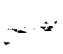

$\therefore$

24

$-v$

...

$x$

×.

$+1$

$-$

$-x$

$\infty$

5 Reynolds testified to Congress in 1965 that US cigarette firms "use lots of 8 second, we use lots of the twenties, and the sixties."16(p300) Given this history and admitted behaviour, assuming two conventional ad exposures per half hour is very conservative, ignoring all brand mentions in sign-ons, segues, sign-offs, and eight-second spots. It is also consistent with a finding six years later by the FTC that 342 shows contained 698 conventional commercials. ${ }^{17}$
ADJUSTING FOR SPOT TELEVISION

Network television show sponsorships were not the only means used by cigarette firms to get television advertising exposure in 1963. All of the US cigarette firms also spent relatively heavily for spot television, the local supplementation of national campaigns. Exposure estimates, therefore, were adjusted upwards assuming that spot television was delivering a similar audience to the network buy. On average, the cigarette firms topped up their network buying with additional spot television buying worth another $30 \%$ of what they spent for network shows. Aggregating for the entire industry was done after adjusting for each firm individually, with "topping up" adjustment factors for spot television ranging from $20 \%$ for RJ Reynolds to $46 \%$ for Liggett \& Myers. Adjustments were made for each firm based on their specific reported spending on network and spot television.

\section{CALCULATING EXPOSURES PER PERSON}

The aggregate audience data, adjusted for spot television, were divided by census information for the size of the various age segments to estimate the number of exposures per week for viewers of various ages. The operational definitions for the age categories were unspecified in the raw data, but subsequent FTC reports on cigarettes contained data where children were defined as either ages $2-11$ or 2-12 years, and correspondingly teens as either 12-17 or 13-17 years. The historical statistics give the US population in 1963 aged $0-13,14-20$, and older, age breaks at slight variance with the apparent FTC categories. The effect of this is conservative, however. Any overestimates of population due to larger age spans defining youth or adolescents would produce underestimates of the number of exposures these ages received.

TIME SLOT PREFERENCE PATTERNS

Using procedures similar to those described above, audience profiles for the total audiences being reached by the total industry's network buys were generated for each half-hour time slot. Rank order correlations were calculated between the observed sponsorship intensity for each time slot and the audience profile characteristics (eg, proportion of teenagers). Reported results focus on half-hour segments within prime time, 19:30-23:00. This excluded weekday soap operas and late-night talk shows where cigarette advertising was irregular and relatively infrequent.

\section{Results}

SPONSORSHIP INTENSITY

A total of 55 network television shows were sponsored by US cigarette firms in the autumn of 1963. Many of the sponsored shows were on the air for an hour or more, and several were on weekdays, while a few were sponsored on 
Table 1 US network TV advertising intensity and audience realization by cigarette firm (autumn 1963) *

\begin{tabular}{|c|c|c|c|c|c|c|}
\hline \multirow[b]{2}{*}{ Firm } & \multicolumn{2}{|c|}{$\begin{array}{c}\text { Network TV advertising } \\
\text { per week }\end{array}$} & \multicolumn{4}{|c|}{ Realised audiences } \\
\hline & Shows & $\begin{array}{l}\text { Half-hour } \\
\text { slots }\end{array}$ & $\begin{array}{l}\% \text { child } \\
(a)\end{array}$ & $\begin{array}{l}\% \text { teen } \\
(b)\end{array}$ & $\% \underset{(c)}{\text { adult }}$ & $\begin{array}{c}\text { Total } \% \text { young } \\
(a+b)\end{array}$ \\
\hline $\begin{array}{l}\text { American } \\
\text { Brown \& Williamson } \\
\text { Liggett \& Meyers } \\
\text { P Lorillard } \\
\text { Philip Morris } \\
\text { R J Reynolds }\end{array}$ & $\begin{array}{r}8 \\
10 \\
9 \\
9 \\
8 \\
11\end{array}$ & $\begin{array}{l}21 \\
22 \\
26 \\
19 \\
18.5 \\
18.5\end{array}$ & $\begin{array}{r}18 \\
8 \\
15 \\
16 \\
18 \\
18\end{array}$ & $\begin{array}{r}12 \\
8 \\
9 \\
9 \\
10 \\
10\end{array}$ & $\begin{array}{l}70 \\
83 \\
76 \\
75 \\
72 \\
72\end{array}$ & $\begin{array}{l}30 \\
17 \\
24 \\
25 \\
28 \\
28\end{array}$ \\
\hline All & 55 & 125 & 16 & 10 & 74 & 26 \\
\hline
\end{tabular}

$\star$ The audience composition data also appear in Proc Am Acad Advertising 1993; 11 (Exhibit 2).

Table 2 Cigarette company sponsorship of US TV shows with audiences of $30 \%$ or more youth [autumn 1963]

\begin{tabular}{|c|c|}
\hline American & $\begin{array}{l}\text { Combat }(45 \%) \text {, Jimmy Dean }(32 \%) \text {, Monday Night Movie }(30 \%) \text {, Saturday Night Movie } \\
(30 \%) \text {, Twilight Zone }(30 \%)\end{array}$ \\
\hline $\begin{array}{l}\text { Brown \& Williamson } \\
\text { Liggett \& Myers }\end{array}$ & Outer Limits $(46 \%)$, Price is Right $(32 \%)$ \\
\hline P Lorillard & $\begin{array}{l}\text { Dick Van Dyke }(33 \%) \text {, Joey Bishop }(44 \%) \text {, Wide World of Sports }(38 \%) \text {, Winter Olympics } \\
\text { Preview }(35 \%)\end{array}$ \\
\hline $\begin{array}{l}\text { Philip Morris } \\
\text { RJ Reynolds }\end{array}$ & $\begin{array}{l}\text { Jackie Gleason }(38 \%) \text {, Red Skelton }(37 \%) \text {, Route } 66(31 \%) \\
\text { Beverly Hillbillies (38\%), Glynis }(44 \%) \text {, McHales Navy }(40 \%) \text {, Sunset Strip }(32 \%) \text {, Saturday } \\
\text { Night at the Movies }(32 \%)\end{array}$ \\
\hline
\end{tabular}

alternate weeks. The bulk of the network sponsorships were for prime-time slots. The large number of sponsored shows and times created an overall pattern of saturation scheduling. The total air time on which cigarettes were advertised was 62.5 hours, or 125 halfhour slots, in the average week. This is equivalent to an average of three hours a day for each of the three major networks then: ABC, CBS, and NBC. The involvement of all six firms and the number of shows and slots bought by them is shown in table 1 . A visual display of the pattern of sponsorship over the week, and exhibits listing the network sponsorship by firm and by time slot, can be seen elsewhere. ${ }^{18}$

\section{AUDIENCES REACHED}

Twenty four programmes each delivered an audience of at least 20 million people per airing that season. The comedy "Beverly Hillbillies" was the biggest hit that season. Over 50 million people watched the show, including 19 million teenagers and children, some $38 \%$ of this show's audience. The US cigarette firms bought successful shows with large reach, and were sponsoring so many shows for so many hours, that the gross audience delivery was stupendous. Table 1 translates these numbers into the proportions of exposures delivered to children, teenagers, and adults by the shows sponsored by the various firms.

The US cigarette firms bought schedules that included 19 programmes with particularly large proportions $(30 \%$ or more) of children and teenagers as seen in table 2. Youth constituted $26 \%$, more than a quarter of the total purchased audience. Only Brown \& Williamson reached a predominately adult audience, buying 10 programmes with all but one delivering $20 \%$ or fewer youthful viewers. In contrast, all the other US cigarette firms bought network television schedules that delivered $24 \%$ to $30 \%$ youth (table 1 ). The null hypothesis that all firms were alike in terms of the youthfulness of their acquired audiences
Table 3 Estimates of exposure to cigarette commercials on US TV, by age [autumn 1963]*

\begin{tabular}{lccc}
\hline $\begin{array}{l}\text { Ad exposures } \\
\text { network \& } \\
\text { spot } T V\end{array}$ & per Week & $\begin{array}{c}\text { per Month } \\
(4.33 \text { weeks })\end{array}$ & $\begin{array}{c}\text { per Year } \\
(52 \text { weeks })\end{array}$ \\
\hline Children & 16 & 70 & 845 \\
Teens & 26 & 112 & 1350 \\
Older & 37 & 162 & 1945 \\
All & 30 & 130 & 1557
\end{tabular}

* These data also appear in Proc Am Acad Advertising 1993; 11 (Exhibit 3).

was rejected by the Kruskal-Wallis analysis of variance $(\mathrm{H}=17.6, \mathrm{df}=5, \mathrm{p}<0.01)$, with Brown \& Williamson the obvious outlier.

\section{NET AD EXPOSURE}

Estimates of the number of television cigarette ad exposures experienced in 1963 by US children, teenagers, and adults are shown in table 3 . On average, children were exposed to cigarette commercials 16 times a week, teenagers 26 times, and adults 37 times. Children growing up in this era would have seen 845 cigarette ads a year on television, increasing to a rate of 1350 cigarette ad exposures as teenagers. Of course, those who watched more or less than an average amount of television would have been subject to that much more or less cigarette advertising on that medium alone. In addition, cigarette advertising inducements would have been experienced from radio, billboards, newspapers, magazines, and retail signage, which received $38 \%$ of the total cigarette spending on measured media.

\section{PROMOTIONAL TIMING PATTERNS}

Not all prime-time slots from 19.30 to 23.00 were equally as popular with the cigarette advertisers. Table 4 presents the amount of sponsorship and the characteristics of the realised audience for the various time slots. This audience data shows a declining proportion of young children watching television as the evening progresses, with teenage viewing 
Table 4 US TV cigarette advertising frequencies and audiences reached by time slot [autumn 1963]

\begin{tabular}{|c|c|c|c|c|}
\hline \multirow[b]{2}{*}{ Time slot $(s)$} & \multicolumn{3}{|c|}{ Audience proportions reached } & \multirow{2}{*}{$\begin{array}{c}\text { Half-hour } \\
\text { sponsored } \\
\text { slots per week }\end{array}$} \\
\hline & $\%$ Child & $\%$ Teen & $\%$ Adult & \\
\hline $14.00-19.30$ & 12.0 & 9.2 & 78.7 & 27 \\
\hline $19.30-20.00$ & 23.4 & 10.3 & 66.4 & 10 \\
\hline $20.00-20.30$ & 23.3 & 10.3 & 66.4 & 11 \\
\hline $20.30-21.00$ & 20.5 & 10.8 & 68.7 & 14 \\
\hline $21.00-21.30$ & 16.0 & 11.1 & 72.8 & 15.5 \\
\hline $21.30-22.00$ & 13.9 & 10.9 & 75.3 & 12.5 \\
\hline $22.00-22.30$ & 8.6 & 9.0 & 82.5 & 11 \\
\hline $22.30-23.00$ & 8.5 & 8.6 & 82.9 & 12 \\
\hline $23.00-00.30$ & 6.5 & 8.5 & 84.5 & 12 \\
\hline
\end{tabular}

also tapering off, but not until after 21.30. The advertising intensity in these prime-time slots was positively and significantly rank-correlated with the proportions of teenagers in the audiences bought $(\mathrm{R}=0.67 ; \mathrm{p}<0.05)$, and was not significantly correlated with the proportions of adults. Because audiences for the occasionally sponsored weekday soap operas and late night talk shows were predominantly adult, inclusion of these would not alter this pattern. These results are consistent with the idea that reaching teenagers was one of the objectives governing television buying.

\section{Discussion}

Television in 1963 delivered an audience to US cigarette sellers that was predominantly, but far from exclusively, adult. While Brown \& Williamson bought a schedule whose audience was $83 \%$ adult, American Tobacco, Philip Morris, and RJ Reynolds each bought television schedules with $28 \%$ to $30 \%$ teenagers and children in their audiences. This might have been the incidental result of media buying criteria selecting those shows for other reasons: their overall ratings, their pricing, and cost per thousand people reached; or where programme content was particularly congenial to smoking, such as the on-screen smoking by a host (Rod Serling on Twilight Zone, sponsored by American Tobacco) or even by medical heroes (Dr Kildare and his mentor Dr Gillespie, sponsored by Liggett \& Myers) ${ }^{19}$ Of course, this could well be the consequence of purchasing policies that systematically preferred programmes that delivered large numbers of underage viewers.

It cannot be concluded with certainty that US cigarette firms were buying television slots in 1963 with the explicit intention of reaching as many teenagers as possible, despite the observed correlation that suggests this. Were appropriate and sufficient data available, one might estimate a discriminant function where sponsorship was modelled as a simultaneous function of the ratings, the audience characteristics, the costs per thousand people reached, and the programme character, generating inferential estimations of the relative import of these factors independent of one another. Far better evidence, however, would be the original corporate media planning documents, but these are not now or ever likely to be available. Without these, the true intentions and targets of the media plans cannot be known with absolute certainty. One can say, however, that the actual purchases of television programmes in the autumn of 1963 directly contradicted the spirit if not the letter of the US industry promise that they would avoid programming that reached television audiences rich with minors. While it may remain uncertain if they were intentionally seeking minors, it is clear that they were definitely not avoiding them. There is no evidence that any US cigarette firm, except for Brown \& Williamson, bought television schedules in autumn 1963 that lived up to the previous summer's suggestions of the Tobacco Institute, despite the assertions by the chief executives of all other cigarette firms that they would do so, or already did. The suggestions of the Tobacco Institute, and the claimed acceptance of these suggestions by the US industry, failed to protect the young from the inducements of television advertising of cigarettes.

1 Greatest cigarette vending machine ever devised! (CBS-TV ad). Advertising Age 1962; 33(26): 64-65.

2 RJ Reynolds gives details of TV sponsorship. US Tobacco $71963 ; 180(10): 5,21$

Philip Morris will sponsor major shows on CBS-TV. US Tobacco f 1963; 180(12): 6, 23.

4 LM to promote 3 brands on 10 network TV shows. US Tobacco f 1963; 180(14): 3

B\&W to sponsor 10 top evening television series. US Tobacco $\mathcal{f} 1963 ; 180(16): 3$

6 Kids see many cigaret ads on TV, FTC finds. Advertising Age $1964 ; 35(16): 1,40$.

7 Tobacco industry to weigh ad code on youth appeals at July 9 meeting. Advertising Age 1963; 34(27): 3 .

8 Don't restrict hours; avoid shows with kid appeal, tobacco men urged. Advertising Age 1963; 34(29): 1, 8 .

9 Kingman M. Top 100 national advertisers spend record $\$ 3.17$ billion on promotion. Advertising Age 1964 ; 35(35) 1,202

10 Federal Trade Commission. A report on cigarette advertising and output. Staff report of the Bureau of Economics. Washington, DC: FTC, 1964.

11 Historical Statistics of the United States, Colonial Times to 1970. Washington, DC: Dep Commerce, Bureau of Census, 1975 Part 1, Series A29-42.

12 Top 100 network TV advertisers for 1963. Advertising Age 1964; 35(14): 64 .

13 Top 100 spot TV advertisers spent $\$ 871,063,000$ in '63. Advertising Age 1964; 35(15): 1, 101

14 Kruskal WH, Wallis WA. Use of ranks in one-criterion variance analysis. $7 \mathrm{Am}$ Stat Assoc 1952; 47: 583-621.

15 Fox S. The mirror makers: a history of American advertising and its creators. New York: William Morrow, 1984.

16 Cigarette labelling and advertising -1965 . Hearing before the Committee on Interstate and Foreign Commerce, House of Representatives, 89th Congress, Ser No 89-11, 1965.

17 Federal Trade Commission. Report to Congress: Pursuant to the Federal Cigarette Labelling and Advertising Act. to the Federal Cigarette Labelli

18 Pollay RW, Compton D. Cigarette ad exposure to youth: TV use under self-regulation [1963]. University of British Columbia, History of Advertising Archives, Working Paper 1992

19 Breed W, DeFoe JR. Drinking and smoking on television 1950-1982. F Public Health Policy 1984; 5(2): 257-70. 